\title{
Who Owns Native Nature? Discourses of Rights to Land, Culture, and Knowledge in New Zealand
}

\author{
Michael Goldsmith*
}

\begin{abstract}
Michael Brown famously asked 'Who owns native culture?' This paper revisits that question by analyzing what happens to culture when the culturally defined boundary between it and nature becomes salient in the context of disputes between indigenous and settler populations. My case study is the dispute between the New Zealand government and Maori tribal groupings concerning ownership of the foreshore and seabed. Having been granted the right to test their claims in court in 2003, Maori groups were enraged when the government legislated the right out of existence in 2004. Though the reasons for doing so were clearly political, contrasting cultural assumptions appeared to set Maori and Pakeha (New Zealanders of European origin) at odds. While couching ownership of part of nature as an IPR issue may seem counter-intuitive, I argue that as soon as a property claim destabilizes the nature/culture boundary, IPR discourse becomes pertinent.
\end{abstract}

\section{INTRODUCTION}

The question of who owns native nature seems like a different sort of question than who owns native culture. In this article I attempt to understand whether this intuition stands up to scrutiny and how it may be linked to a set of cultural assumptions that may or may not be shared with others.

In the process I examine the old anthropological adage that people of different cultural backgrounds delimit the boundary between nature and culture differently. For certain actors this means even explicitly denying the boundary altogether, a strategy pursued by some indigenous legal activists, ${ }^{1}$ but usually by

\footnotetext{
^University of Waikato. Email: mikegold@waikato.ac.nz
} 
instituting equally powerful distinctions, or more implicit versions of the nature/ culture boundary, elsewhere. In any event where, how, and whether people draw and redraw the boundary has implications (and here I cite a few references solely from anthropology) not just for how they treat the environment in general ${ }^{2}$ but also for how they treat other animal species, ${ }^{3}$ humans of other races, ${ }^{4}$ and members of the opposite gender. ${ }^{5}$

If it is true that people of different cultural backgrounds delimit the boundary between nature and culture differently, how does that shape and complicate a number of issues that are the focus of continued and vexed debate in New Zealand? Not surprisingly, most issues arise in the context of relations between the two most important and allegedly culturally distinct populations of Māori and Pākehā, the latter a contested label for whites or people of European descent. ${ }^{6}$ I cannot address all such issues here, but I include two that would be worthy contenders if I had more space. The first is an ongoing claim to the intellectual property surrounding some iconic plant and animal species, lodged before the Treaty of Waitangi Tribunal (WAI 262). ${ }^{7}$ However, for reasons that have precisely to do with disagreements over the nature/culture boundary, proponents of the claim argue that intellectual property is something of a misnomer, preferring the broader phrase cultural and intellectual heritage rights or the Māori term taonga (see the following text). The second issue has to do with the question of Mãori opposition to certain kinds of genetic research and modification or engineering in the fields of medicine and agricultural production. ${ }^{8}$ The claims here have more to do with rights to veto the inappropriate mixing of genetic constitutions and genealogies (whakapapa).

Although each issue would clearly lend itself to the kind of interrogation previously outlined, my topic may strike readers as needing more justification. As far as I know, it has never been couched as an issue of intellectual property rights (IPRs), and doing so may seem like a category error. Nevertheless, as soon as a property claim destabilizes the nature/culture boundary, the possibility of using IPR discourse enters the fray.

The main case study on which I draw to illustrate these questions, then, is the so-called foreshore and seabed dispute in New Zealand, which has led to the politicization of both culture and nature and so is a matter of continuing ideological debate. But it also suits my analytical purposes well. This contention is supported by arguments proposed for Melanesian cultures by Marilyn Strathern ${ }^{9}$ and Andrew Moutu. ${ }^{10}$ In the Melanesian context, land can be conceived of as a kind of intellectual property. In fact, it turns out that real and intellectual properties may not be as distinct in the Western context as most commentators, including Strathern, assume.

As in some of my previous attempts to grapple with questions surrounding cultural identity in New Zealand, ${ }^{11}$ I start from an anthropological axiom of cultural symmetry. That means everyone takes part in culture, has culture, and is cultural to the same extent. But I am aware that not everyone in New Zealand 
sees things that way, which affects how they take part in culture. They sometimes do so, for example, on the basis of what I regard as the misguided assumption of cultural asymmetry, which shapes political debates and underpins the policies of many governmental and nongovernmental bodies. I also recognize that the underlying cultural symmetry may coexist with political inequality, as in the oppression and marginalization of indigenous peoples. Nevertheless, I do not see how a truly anthropological analysis can subscribe au fond to the view that some actors are more cultural than others. For this reason, I believe anthropology can provide a useful perspective on debates in New Zealand cultural politics, even if anthropological perspectives do not lend themselves to easy black-and-white solutions.

\section{THE CULTURE OF NATURE}

The title of this article plays with the now-famous phrase that forms the title of Michael Brown's important and influential book ${ }^{12}$ on issues of culture and ownership: Who owns native culture? However, I am not simply borrowing his formulation to direct attention to a different sphere and add to the debate by extending the reach of his argument. I ask a different question and effectively question his question. If one replaces culture in his question with nature, interesting things happen to culture.

To start with, my title's rephrased question verges on the rhetorical or the redundant. Who owns native nature intuitively sounds more straightforward to my ears than who owns native culture, because if nature is native, surely-as the question already assumes_-it is by definition already owned by natives. It's like asking the apparently tautological question, Who owns my house? The immediate presumption is that I own my house. True, the reality could turn out to be more complex: The answer could be me plus my partner, my spouse, my parents, my landlord, my bank, the state, and so forth. But even if I do not actually or wholly own my house, there will be little doubt that the house is, firstly, owned in some identifiable way and, secondly, owned by some person or persons identifiable in law, either in their own right, acting as agents for others, or represented by institutions. To paraphrase Honoré, ${ }^{13}$ ownership can be regarded simply as the greatest possible interest in a thing whose ownership is legally recognized. In my world, which is strongly influenced by the Anglo-American and European legal tradition, finding out who owns a house thus becomes a matter for empirical, rather than philosophical, investigation.

Part of what I am trying to do here, however, is to work out why the question of the ownership of cultural and intellectual property is not usually treated as similarly clear-cut in principle. To put it another way, one has to ask why anthropologists, legislators, and IPR consultants have not generally deemed Brown's question to be rhetorical (in the sense of superfluous because the answer is sup- 
posedly obvious). It may have to do with the fact that culture, in the broadest anthropological sense, has not been treated as property by Western legal regimes, unlike almost everything else. Indeed, there is a relentless logic at work that seems bent on bringing more and more of the material world under property regimes (e.g., potable water, deep-water fish species, and carbon credits). Those parts of the material world that have (so far) been excluded from ownership claims (e.g., international waters, Antarctica, and outer space) may either become subject to such claims or must continue to be explicitly excluded from such considerations by international treaties and conventions, thus confirming the point. True, bits of culture are classifiable as property-under copyright and patent provisions, for example-but the broader question of who owns Western culture does not offer as much purchase as who owns native culture. The latter seems like a question arising from the necessity of having to rethink cultural property in the face of claims to rights in cultures as wholes, stemming from indigenous challenges to Western property law. One interesting consequence may be that who owns Western culture will become a much more conceivable and feasible question in the future, but first it must lose its unmarked character vis-à-vis the culture of indigenous minorities. In the absence of a major world-historical political change, I consider that unlikely.

That I find the question of ownership complicated when transferred from one domain to another has to do with a widespread assumption concerning the different ontological (or even the epistemological) status of culture as compared to nature. On this view culture, like all knowledge, can be owned by more than one person or by no identifiable person at all; and it is not a thing in the same way as nature or material things. Nature must always have a material basis, at least according to common sense. Here, nature refers to things that have a material existence, including segments of the natural environment, concrete objects (whether natural or produced by cultural action), and aspects of people's own biological being, such as their bodies, body parts, and genetic constitution.

If we assume that nature and culture have different ontological statuses and are therefore subject to somewhat different ownership claims, we could argue that culture preeminently concerns claims via the politics of recognition, whereas nature preeminently concerns claims via the politics of redistribution. ${ }^{14}$ The first kind of politics assumes that everyone deserves respect and recognition on the non-zero sum basis of group membership of some sort; the latter approach, by contrast, assumes that not everyone can muster equal ownership claims and is therefore predicated on zero sum logic. To put it another way, culture as a transferable good is not inherently diminished, in any strict sense, by being appropriated by others, whereas nature as the material world is inherently limited. As has often been noted in relation to real estate, no one is making any more of it, whereas the domain of culture is ceaselessly invented and inventive. For just this reason, incidentally, the logic of joint stewardship, which is Brown's proposed solution ${ }^{15}$ to conundrums of cultural ownership, may not convince indigenous 
peoples working in partnership with nonindigenous others to resolve disputes over the ownership of nature (especially land). After all, why would indigenous groups voluntarily concede to the theft of some or all the property that they already (believe they) own?

Yet one complicating factor in setting out my argument is precisely the difficulty of maintaining a clear separation between nature and culture in specific cases, a difficulty shared by most New Zealanders, Māori and non-Māori alike. Even if New Zealanders talk as though the distinction is clear, it tends to collapse or at least to blur in practice. As a consequence, conflicts over intellectual (or, as I prefer, cultural) property inevitably generate questions concerning material (or natural) property-and vice versa.

The boundary between nature and culture is therefore always problematic. If nature has a cultural dimension to it, such a distinction will never be entirely clearcut: Bodies, landscapes, and material objects are culturally shaped. Individual cultures draw the boundary differently, and their rhetorical justifications for doing so are always, by definition, cultural. Moreover, one of those cultural/rhetorical strategies may be to argue that certain cultures do not maintain such a separation, that to maintain one is itself a sign of alienation from nature. The argument has an even deeper resonance in some circles. This notion of the interpenetrability (or even inseparability) of nature and culture is in fact crucial to many nativist discourses of ownership. It should come as no surprise, therefore, that such notions arise in the discourse surrounding the Treaty of Waitangi in New Zealand. This is not the place for an extended history of the treaty and the evolution of accompanying claims and settlement processes, but a quick sketch may be in order for some readers.

The treaty was signed in February 1840 as an instrument to construct an orderly relationship between the British Crown and Māori leaders, guaranteeing Māori the status of British subjects and the continued possession of their property while getting them to concede sovereignty (or something less than sovereignty) to the Crown. This last point is most contentious, because the English version of the treaty document uses the term sovereignty, whereas the Māori treaty uses a missionary-inspired neologism kawanatanga (literally governorhood), which many Māori negotiators argue is a much more circumscribed notion. This view of that part of the treaty is supported by some lawyers, historians, and constitutional experts and disputed by others. Clearly, for much of the nineteenth century and the first half of the twentieth century, the British and successor New Zealand governments assumed that sovereignty had been ceded to the Crown, an interpretation that underpinned British settlement and land alienation, in addition to justifying military action when Māori resisted. Although indigenous protest never died away entirely, it was not until the Māori renaissance of the 1960s and 1970s that a reassessment of the treaty gained much traction. In response, the Waitangi Tribunal was set up in 1975 to investigate ongoing claims and injustices (i.e., issues arising from that point onward). A decade later, in a move of 
great historical significance, the tribunal's purview was retrospectively expanded to include claims going back to the date of the treaty's signing. The tribunal cannot compel the government to act in any way, but it has the power to research historical findings and to make recommendations that have varying degrees of force. Under its aegis some major claims have been settled, at least for the interim, but many remain and controversy clouds some that have been nominally resolved. ${ }^{16}$

To return to my main argument, in the stated view of some Māori, land and material objects (whether culturally produced or not) are canonically said to have wairua or spirituality, to not be exclusively natural in the way that Western science supposedly assumes. ${ }^{17}$ This conflation of natural and cultural may be intensified by the designation of goods that fall into each category as taonga. Translated most frequently as treasures or valuables, taonga consist of an open-ended series of goods, the rights to which are guaranteed under article 2 of the Treaty of Waitangi but the definitions of which are open to debate. Because claims adjudicated on in Waitangi Tribunal judgments have applied to taonga as diverse as lands, fisheries, and the Māori language itself, the referents of the term clearly include both material and cultural or intellectual property.

The issue becomes even more complex when cultural and linguistic phenomena come into play. For example, ownership claims in Māori and other Polynesian languages are inflected by an inherent distinction between possessive articles that imply either alienability or inalienability (the well known $a$ versus $o$ opposition). To say that something is mine or ours may therefore imply something other than straightforward ownership in the Western sense.

In addition, the fact that some claims to both cultural and natural property have a perduring quality may stem from quite different logics of ownership (at least as expressed in legal argument). On this view, indigenous cultural property is owned in perpetuity because it is owned not by individuals but, as Brown ${ }^{18}$ describes, by groups that in principle could live forever (thereby circumventing the time-limited provisions of patent and copyright regimes). Indigenous natural property, by contrast, is ultimately owned in perpetuity—like everyone else's-because if it is subject to a claim for return or redress, it can only be because the property was earlier alienated by force or fraud and not because of some presumed difference in the legal status of the owner. If (and this is a big if) it was not alienated in those ways, it unequivocally belongs to some other party, not to indigenous people organized in traditional ways. In principle, therefore, Western law is perfectly compatible with both indigenous and nonindigenous claims to nature in perpetuity, even if in practice that principle has often been ignored or manipulated when it comes to indigenous minorities in settler societies.

The nature/culture distinction tends to blur at precisely this point, however. One cultural difference between capitalist and noncapitalist notions of property is that the latter sets no time limit (or perhaps it sets indefinitely long time limits) on the ownership of culture. Western capitalist regimes, by contrast, allow such 
longevity only in the case of nature: One owns land or material property unless and until it is alienated. Intellectual/cultural property is a different matter. It is time delimited, often in some formulaic proportion calibrated to the lifespan of the owner. One might say that the individualistic nature of such ownership is embodied, a point derived from C.B. Macpherson's analysis of the rise of possessive individualism. ${ }^{19}$ This work treats as historically pivotal the development of a modern axiom that first and foremost individuals own themselves.

Perhaps it is time to introduce the antiphonal phrase possessive collectivism to capture the notion that (indigenous) groups possess one thing above all others: their culture. Indeed, at one level, the group is the culture, the origins of which are presumed to be ancient and the existence of which is treated as timeless - an ideological convenience within what has come to be known in anthropological circles as the politics of tradition. This well-known strategy can apply creatively to much more than the canonically authentic parts of indigenous cultures. After the release of the film based on his novella Whale Rider, writer and leading figure of the contemporary Māori cultural renaissance Witi Ihimaera stated that he took "a tribal approach to writing." He continued, "I would much prefer that I was better known as a person who has helped the entire Māori literary tradition rather than my own career." $^{20}$

It is as if, rather than individuals owning cultures (or bits of cultures), their cultures possess them. There is a clear analogy between this idea of people being owned by their cultures and indigenous rhetorics surrounding land and other parts of the (natural) environment. I have heard, for example, some Māori assert that their land owns them, rather than the other way around. Land and culture in this respect are both conceptualized (culturally, of course) as inalienable.

If, as in some indigenous perspectives, no temporal limits are applied to curtail ownership (and of course it is only cultural convention that requires such curtailment), the ownership of nature and the ownership of culture are placed on the same footing. In short, for practical purposes, culture and nature merge. In some versions of this argument, it was only Western thought that ever conceived of separating them in the first place.

\section{THE SEABED AND FORESHORE CONTROVERSY: NATURAL INJUSTICE?}

Consider a case study of particular significance to New Zealand in the opening years of the twenty-first century. The recent and ongoing seabed and foreshore dispute reveals legal and historical divisions, but it also sheds light on some deepseated cultural splits. Because it has generated a storm of commentary from almost every conceivable viewpoint, I can only scratch the surface. ${ }^{21}$

The controversy came to a head in 2004 when Māori from around New Zealand marched and mobilized against the Labour government's move to pass leg- 
islation denying Māori groups the right to subject claims for seabed and foreshore ownership rights to legal arbitration. This action effectively deprived Māori of a natural avenue of justice to test their legal rights. The government's course of action was dictated by what it saw as the political unacceptability of an outcome in which segments of the New Zealand coastline, previously deemed public domain, could be ruled to be the freehold property of tribal or subtribal groups. Never mind that by some estimates a third of the coastline is already in private hands and will never be returned to public ownership. At one level the move was simply racist oppression of a minority for reasons of realpolitik. At another level, however, the cultural grounds on which the political unacceptability rested were real and deserve some scrutiny.

So how does the seabed and foreshore controversy relate to the theoretical meanderings earlier in the article? Land, seabed, and foreshore are always subject to claims of exclusive ownership, but as an iconic identity marker the foreshore is never owned exclusively.

Let me quickly clarify two aspects of this assertion. First, as the Court of Appeal legal decision suggests, ${ }^{22}$ areas of seabed and foreshore are subject to rules and laws of land tenure, not marine tenure. It is my understanding that issues of water ownership are not at stake; those issues affect the land under and next to it, even though the areas in question are clearly defined in relation to bodies of water. Whether it is a matter of land or sea or both may be one issue where cultural differences are most accentuated, however, since some Māori groups have not only lodged claims to the customary ownership of water courses and marine resources but have also resisted certain development projects on the grounds that they would lead to the inappropriate mixing of waters from two different sources. ${ }^{23}$ This is an argument clearly analogous to the opposition to genetic tinkering alluded to earlier.

Second, from a non-Māori perspective, the political storm surrounding the seabed and foreshore issue stems from a fear fanned by populist politicians: Allowing Māori groups to assert ownership of these pieces of land would prevent the rest of society from gaining access to beaches. In this version of the white New Zealand imaginary, bits of foreshore may be for private use but beaches are for everyone. The beach (as it is often called) represents a complex myth composed of freedom (from work, convention, clothes), access to fishing and other nautical pursuits, and nostalgia for the great New Zealand summer holiday. (Bruce Mason's play, The End of the Golden Weather, which he performed as a one-man show at possibly every New Zealand school in the 1960s, is the ur-text for this myth.) The difficulty is that the Pākehā beach (or its mythology) is threatened by many sources, not just Māori claims - in fact probably less from Māori reassertion of customary ownership than from land sales to foreign and local developers for seaside resorts, golf courses, and private paradises. One aspect of the old mythology rested on the availability of coastal camping grounds for cheap holidays. As the owners of the land on which many traditional camping grounds were located have sold it off to private homeowners and developers (such land having appreciated greatly in value 
in the last few years), in early 2006, the then Labour-led government even floated the quixotic idea of setting up new camping facilities on public land, allowing bidding for suitable sites as they come on to the market. ${ }^{24}$

In the 2005 election campaign, the National Party almost wrested power from the Labour party by appealing to voters with an advertising campaign that was widely regarded as more successful than that of the incumbent government. The most effective part of that campaign was a series of billboards attributing a message to Labour in the left half of the billboard against a red background and the National riposte in the right half of the billboard against a blue background. (By historical convention, eerily echoed in the regalia of youth gangs based on the Bloods and Crips division borrowed from Los Angeles gangster culture, red and blue are in fact their respective colors.) Portraits of the two party leaders in their particular billboard halves made the messages even clearer. The most effective billboards were among the simplest and earliest erected. One placed the caption TAX on the Labour side and the caption CUT on the National side. Enough said. Another, more germane to my topic, also juxtaposed the words IWI and KIWI under a heading BEACHES that straddled the entire billboard. Iwi is a widely used term for Māori tribal groupings; Kiwi is the Māori name for a native species of flightless bird as well as an unofficial term for a New Zealander. For various reasons many people who object to the label Pākehā readily embrace Kiwi, perhaps because Kiwi can theoretically apply to someone of any ethnicity, and the argument that "we are all New Zealanders" (i.e., without regard to race) is popular. In practice, however, the name is often understood as applying to mainstream or nonMāori New Zealand. I believe that was the tacit meaning behind the billboard: Labour made (or would make) special interest deals with Māori iwi that deprived ordinary New Zealanders of a right that made them New Zealanders.

Labour tried to forestall such a political reaction by passing the aforementioned legislation, but as the party that had long claimed a special relationship to Māori (and had won all seven Māori seats in the previous election), it was vulnerable to the changing terms of the race debate. In the 2005 election, caught in a squeeze between National's populist campaigning and more radical Māori policies, Labour retained three seats but lost four to a new Māori Party, whose coleader had defected from Labour largely because of Labour's stance on the foreshore and seabed issue.

The foreshore and seabed dispute derives much of its ferocity from an ongoing tension in New Zealand political discourse between, on one hand, privatization/ private ownership and control and, on the other hand, ideologies of collectivism and the common good. I can only give a taste of the historical complexities here, but they are strongly shaped by two currents of legal precedent. The first is a popular discourse taken from British law and Western political ideology that highlights the need to protect public access to the commons. The second is a discourse concerned with protecting specific treaty rights pertaining to indigenous peoples. At the risk of oversimplification, the former focuses on class, the latter on culture. 
The colonial connection is responsible for both. That is to say, settlers introduced a Western-style system of classes with all the conflict such a system presupposes, while the Treaty of Waitangi reflected longstanding imperial doctrines concerning the proper treatment of the native populations. Said doctrines attempted to maintain a delicate balance between indigenous ideas of property and hierarchy and introduced ideas of property that animated class and class conflict.

The mythology of rights that stem from the British common law tradition (the Queen's chain, "an Englishman's home is his castle," etc.) remain powerful in New Zealand. But they are inevitably inflected and deflected by the influence of Māori notions of ownership and guardianship, disputes over dispossession, extinction of land rights under colonialism, and redress through the Treaty of Waitangi and courts (including Māori land courts).

Class is the defining principle of property in Britain. The right to walk in the countryside is the assertion of a class right against upper class landowners. Transferred to New Zealand, this principle lent a powerful impetus to the actual breakup of large run-holdings in the North Island toward the end of the nineteenth century. This continues in the present day by means of a program of revising the terms of large leasehold properties in the South Island high country. But those changes in ownership disadvantaged only a minority of the settler population, whose rights have never been the focus of widespread political support. As such, there are precedents in British history in the form of progressive tax regimes, occasional nationalization of resources, and the steady erosion of aristocratic privilege-most of which apply or have been tested in New Zealand. In some New Zealand contexts, however, the notion of property has become culturalized to a much larger extent than in the mother country. In the latter the development of property law has largely eclipsed and certainly takes precedence over what might be called prior forms of property. The matter is not so settled in New Zealand where, through the treaty settlement process, ostensibly Crown property (including the foreshore and seabed) is subject to claims from groups who do not represent the majority of individual citizens. As a consequence the foreshore and seabed issue revolves around the very definition of property. Is it individual or collective, alienable or inalienable? These are more than matters of class-based distributive justice; rather, they shape the creation and/or recognition of historically and culturally differentiated groups within society.

Ironies abound. The New Zealand debate over the foreshore and seabed in effect opposes those who wish to apply an individualist concern for property rights (but safeguarded by the state that allows some unrestricted public access to beaches) to those who wish to apply rights based on descent that are reminiscent of the aristocratic rights that have been constrained in Britain! A recognized authority on the history of New Zealand identity and race relations supports my argument:

"One of the essences of Pākehā New Zealandness is the notion that certain resources are freely available to all people," says University of Auckland historian James Belich. The condition is deeply rooted in the $19^{\text {th }}$ 
Century, when settlers came from Britain, where the lower classes were not entitled to hunt, fish, or have leisure. "There is a deep-seated nerve being drummed here. Whether it's been done deliberately or reasonably is another matter," Belich says. ${ }^{25}$

At least one religious studies expert has described the controversy as an instance of "landscape paganism." According to Mike Grimshaw of the University of Canterbury, "The seabed-and-foreshore thing was a religious debate, about the beaches being sacred spaces that bind us together and split us apart." ${ }^{26}$ Ironically, the people he had in mind as adherents of this new religion are almost certainly Pākehā.

\section{CULTURALLY DIFFERENT IDEAS OF PROPERTY?}

The final part of this article returns briefly to the question of the extent to which there really are culturally different ideas of property in New Zealand or indeed elsewhere. As noted in the introduction, Andrew Moutu picks up on Marilyn Strathern's assertion that in many parts of Melanesia land can be conceived as a kind of intellectual property. On this view intellectual property is real property (as in the real of real estate), a conceptual move made possible by means of a dialectical flip from seeing ownership functioning as a "technology to enhance and stimulate further creativity" to seeing creativity functioning as a "technology that perpetuates ownership." ${ }^{27}$ In so saying, both authors question what Strathern calls the Western distinction between tangible and intangible property. More importantly, the argument she proposes, and Moutu elaborates through his case study of the ownership of an oxbow lake in the Sepik River system, also questions the distinction between entitlements based on the productivity of human labor and entitlements based on intellectual activity. Of course, at least one Western philosophical tradition, Marxism, has long questioned that distinction, but it has done so by subsuming intellectual labor within (nonalienated) productive labor. For Marx value was created by labor, and property relations should reflect that fact-a theory that the Sepik clan members seemed to reject when they explained their views to Moutu. For them, the crucial right has less to do with how much work people put into the creation of an oxbow lake than whether they have the right to work on its creation on the first place.

Nevertheless, in this generally fruitful and stimulating reconceptualization of cultural difference, it would be unwise to regard Western cultural systems of property as monolithic. The existence of a Marxist tradition unsettles the notion of a capitalist cultural system, however hegemonic that system has become, and we should note that the labor theory of value was itself a reaction to an earlier physiocratic theory of economy. Developed in the seventeenth century under the patronage of the French monarchy (with its real interests in real property), this theory maintained that land and agriculture were the real source of real value. It also 
placed this value system at the basis of the natural order, which is to say the cultural order with its culturalness camouflaged. Now, according to Moutu, Strathern acknowledges eighteenth-century British views comparing intellectual property to the activity of tilling the soil, but in terms of her overall argument, this seems to be an afterthought. The Melanesian view of property may turn out to be much closer to the physiocratic one than the bulk of Strathern's work on non-Western systems of property and personhood otherwise recognizes.

The question, then, is not just who owns nature or culture, in part or in whole, but who has the right to define which of these is which and how much of each is ownable. The answers to those questions are partly matters of culture, but the cultural values in question are shaped by a multitude of other factors: legal traditions, historical changes in production, claims of class allegiance, and (in the case of the New Zealand foreshore and seabed dispute) relations of power in colonial societies.

\section{ENDNOTES}

1. For example, Battiste and Henderson, Protecting Indigenous Knowledge, 146-50.

2. Descola and Pálsson, Nature and Society, and Escobar, "After Nature."

3. Kohn, "How Dogs Dream."

4. Wade, Race, Nature and Culture.

5. MacCormack and Strathern, Nature, Culture and Gender.

6. Goldsmith, "Being Pakeha Then."

7. Solomon and Watson, "The Waitangi Tribunal," Solomon, "The Wai 262 Claim," and Masters, "All Things Bright"; see also van Meijl, this issue.

8. Haami and Roberts, "Genealogy as Taxonomy," Reynolds and Smith, Aue! Genes and Genetics, and Roberts et al., "Whakapapa."

9. "The Patent and the Malanggan" and Kinship, Law and the Unexpected.

10. This volume.

11. Goldsmith, "Our Place," "Culture, For and Against," and "Culture in Safety."

12. Who Owns Native Culture?

13. "Ownership."

14. Van Meijl and Goldsmith, "Introduction: Recognition"; following, for instance, Taylor, "The Politics of Recognition," and Fraser, "From Redistribution to Recognition?"

15. "Can Culture Be Copyrighted?" and Who Owns Native Culture?

16. For a representative selection of views on these matters, see Belgrave, Kawharu, and Williams, Waitangi Revisited, Byrnes, The Waitangi Tribunal, Hayward and Wheen, The Waitangi Tribunal, Kawharu, Waitangi: Maori and Pakeha, Orange, The Treaty of Waitangi, and Ward, An Unsettled History.

17. Collins, "Maori Alarm."

18. "Can Culture Be Copyrighted?"

19. The Political Theory.

20. Black, "Lucky to Be Born," G2.

21. For a taste of the debate, which is beginning to include some important academic interventions, see Ansley, "Stakes in the Sand," Berry, "Troubled Waters and Hidden," CANZ, Catholic Submissions and Statements, Epstein, The Foreshore and Seabed, Erueti and Charters, Maori Property Rights, Greensill, "Foreshore and Seabed Policy," Johnston, "Foreshore and Seabed Act," National Party, "What Labour Doesn't Want," NZH, "The Foreshore and Seabed Bill," Ruru, "A Politically Fuelled Tsunami," van Meijl, "The Paradox of Indigenous," and Waitangi Tribunal, Report on the Crown's Foreshore. 
22. AILR, "Ngati Apa v Attorney-General," 48.

23. McCan and McCan, Water: Towards a Bicultural.

24. Eames, "100 New Campaign Grounds."

25. Walsh, "Forecast: Storm," 46.

26. Harvey, "Soul Searching," B4.

27. See Moutu's figure, Trajectories of Ownership: A Schematic Representation, in this issue.

\section{BIBLIOGRAPHY}

AILR. "Ngati Apa v Attorney-General [2003] NZCA 117." Australian Indigenous Law Reporter 8, no. 2 (2003): 47-55.

Ansley, Bruce. "Stakes in the Sand." New Zealand Listener (May 1) 193, no. 3338 (2004): 16-21.

Battiste, Marie, and James [Sa'ke'j] Youngblood Henderson. Protecting Indigenous Knowledge and Heritage: A Global Challenge. Saskatoon: Purich Publishing, 2000.

Belgrave, Michael, Merata Kawharu, and David Williams, eds. Waitangi Revisited: Perspectives on the Treaty of Waitangi. Melbourne: Oxford University Press, 2005.

Berry, Ruth. “Troubled Waters and Hidden Obstacles.” New Zealand Herald (October 13, 2004): A18.

Black, Eleanor. “Lucky to Be Born a Maori.” New Zealand Herald, January 25, 2003, G1-G2.

Brown, Michael F. “Can Culture be Copyrighted?” Current Anthropology 39, no. 2 (1998): 193-206.

Who Owns Native Culture? Cambridge: Harvard University Press, 2003.

Byrnes, Giselle M. The Waitangi Tribunal and New Zealand History. Auckland: Oxford University Press, 2004.

CANZ. Catholic Submissions and Statements on the Foreshore and Seabed Bill 2004. Wellington: Caritas Aotearoa New Zealand, 2004.

Collins, Simon. "Maori Alarm at Gene Project.” New Zealand Herald, April 25, 2005, A8.

Descola, Philippe, and Gísli Pálsson, eds. Nature and Society: Anthropological Perspectives. London: Routledge, 1996.

Eames, David. “100 New Camping Grounds in Offing.” New Zealand Herald (January 10, 2006): A1.

Epstein, Richard A. The Foreshore and Seabed. Wellington: New Zealand Business Roundtable, 2005.

Erueti, Andrew, and Claire Charters, eds. Maori Property Rights and the Foreshore and Seabed: The Last Frontier. Wellington: Victoria University Press, 2007.

Escobar, Arturo. "After Nature: Steps to an Antiessentialist Political Ecology." Current Anthropology 40, no. 1 (1999): 1-30.

Fraser, Nancy. "From Redistribution to Recognition? Dilemmas of Justice in a 'Post-Socialist' Age." New Left Review 212 (1995): 68-93.

Goldsmith, Michael. "Being Pakeha Then: The Genealogy of an Ethnic Label in New Zealand Mythistory." La Nouvelle Revue du Pacifique/New Pacific Review 3 (2006): 55-64. 
. "Culture, For and Against: Patterns of 'Culturespeak' in New Zealand." In "Postcolonial Dilemmas: Reappraising Justice and Identity in New Zealand and Australia," edited by Toon van Meijl and Michael Goldsmith. The Journal of the Polynesian Society 112, no. 3 (2003): 280-94.

—. "Culture in Safety and in Danger." Anthropological Forum 15, no. 3 (2005): 257-65.

. "'Our Place' in New Zealand Culture: How the Museum of New Zealand Constructs Biculturalism.” Ethnologies Comparées 6 (Spring 2003). Available at http://alor.univ-montp3.fr/cerce/ revue.htm (accessed 30 October, 2009).

Greensill, Angeline. "Foreshore and Seabed Policy: A Maori Perspective." New Zealand Geographer 61, no. 2 (2005): 158-60.

Haami, Brad, and Mere Roberts. “Genealogy as Taxonomy.” International Social Science Journal 54, no. 173 (2002): 403-12.

Harvey, Claire. "Soul Searching." New Zealand Herald (December 31, 2005): B1, B3-B4.

Hayward, Janine, and Nicola R. Wheen, eds. The Waitangi Tribunal: Te Roopu Whakamana i Te Tiriti o Waitangi. Wellington: Bridget Williams Books, 2004.

Honoré, A.M. "Ownership." In Oxford Essays in Jurisprudence, edited by A.C. Guest, 107-47. Oxford: Clarendon Press, 1961.

Johnston, Peter. "Foreshore and Seabed Act 2004: Frequently Asked Questions." Te Pouwhenua 30 (October 2005): 6-7.

Kawharu, I.H., ed. Waitangi: Maori and Pakeha Perspectives of the Treaty of Waitangi. Auckland: Oxford University Press, 1989.

Kohn, Eduardo. "How Dogs Dream: Amazonian Natures and the Politics of Transspecies Engagement." American Ethnologist 34, no. 1 (2007): 3-24.

MacCormack, Carol P., and Marilyn Strathern, eds. Nature, Culture and Gender. Cambridge: Cambridge University Press, 1980.

Macpherson, C.B. The Political Theory of Possessive Individualism: Hobbes to Locke. London: Oxford University Press, 1962.

Masters, Catherine. “All Things Bright and Beautiful." New Zealand Herald, June 9, 2007, B5.

McCan, Cindy, and David C. McCan. Water: Towards a Bicultural Perspective. Information Paper no. 23. Lincoln: Centre for Resource Management, 1990.

Meijl, Toon van. "The Paradox of Indigenous Rights: The Controversy Around the Foreshore and the Seabed in New Zealand." In Public Policy and Ethnicity: The Politics of Ethnic Boundary Making, edited by Elizabeth Rata and Roger Openshaw, 66-80. Basingstoke: Palgrave Macmillan, 2006.

Meijl, Toon van, and Michael Goldsmith. "Introduction: Recognition, Redistribution and Reconciliation in Postcolonial Settler Societies." In "Postcolonial Dilemmas: Reappraising Justice and Identity in New Zealand and Australia," edited by Toon van Meijl and Michael Goldsmith, The Journal of the Polynesian Society 112, no. 3 (2003): 205-18.

National Party. "What Labour Doesn't Want You to Find in the Foreshore and Seabed Bill." Advertisement. New Zealand Herald, June 29, 2004, A13.

NZH. "The Foreshore and Seabed Bill Explained.” New Zealand Herald, November 18, 2004, A6. 
Orange, Claudia. The Treaty of Waitangi. Wellington: Bridget Williams Books, 1987.

Reynolds, Paul, and Cherryl Waerea-i-te-Rangi Smith. Aue! Genes and Genetics. Wanganui: Whanganui Iwi Law Centre, 2002.

Roberts, Mere, Brad Haami, Richard Benton, Terre Satterfield, Melissa L. Finucane, Mark Henare, and Manuka Henare. "Whakapapa as a Maori Mental Construct: Some Implications for the Debate over Genetic Modification of Organisms." The Contemporary Pacific 16, no. 1 (2004): 1-28.

Ruru, Jacinta. "A Politically Fuelled Tsunami: The Foreshore/Seabed Controversy in Aotearoa me te Wai Pounamu/New Zealand." Journal of the Polynesian Society 113, no. 1 (2004): 57-72.

Solomon, Maui. “The Wai 262 Claim: A Claim by Maori to Indigenous Flora and Fauna: Me o Ratou Taonga Katoa." In Waitangi Revisited: Perspectives on the Treaty of Waitangi, edited by Michael Belgrave, Merata Kawharu, and David Williams, 213-32. Melbourne: Oxford University Press, 2005.

Solomon, Maui, and Leo Watson. "The Waitangi Tribunal and the Maori Claim to their Cultural and Intellectual Heritage Rights Property." Cultural Survival Quarterly 24, no. 4 (2001): 46-50.

Strathern, Marilyn. Kinship, Law and the Unexpected: Relatives Are Always a Surprise. New York: Cambridge University Press, 2005.

—. "The Patent and the Malanggan." Theory, Culture and Society 18, no. 4 (2001): 1-26.

Taylor, Charles. "The Politics of Recognition." In Multiculturalism and 'The Politics of Recognition,' edited by Amy Guttman, 25-103. Princeton, NJ: Princeton University Press, 1992.

Wade, Peter. Race, Nature and Culture: An Anthropological Perspective. London: Pluto Press, 2002.

Waitangi Tribunal. Report on the Crown's Foreshore and Seabed Policy-WAI 1071. 2004. Available at http://www.waitangi-tribunal.govt.nz/reports/view.asp?ReportID=838C5579-36C3-4CE2-A444E6CFB1D4FA01 (accessed 30 October, 2009).

Walsh, Frances. "Forecast: Storm." Metro, November 2003, 44-51.

Ward, Alan. An Unsettled History: Treaty Claims in New Zealand Today. Wellington: Bridget Williams, 1999. 